\title{
GENDER AND SEX HORMONES INFLUENCE THE RESPONSE TO TRAUMA AND SEPSIS - POTENTIAL THERAPEUTIC APPROACHES
}

\author{
Martin K. Angele, ${ }^{a}$ Markus C. Frantz, ${ }^{b}$ Irshad H. Chaudry ${ }^{\text {c }}$
}

Angele MK, Frantz MC, Chaudry IH. Gender and sex hormones influence the response to trauma and sepsis-potential therapeutic approaches. CLINICS. 2006;61(5):479-88.

Several clinical and experimental studies have demonstrated gender dimorphism in immune and organ responsiveness and in the susceptibility to and morbidity from shock, trauma, and sepsis. In this respect, cell-mediated immune responses have been shown to be depressed in males following trauma-hemorrhage, whereas they were aintained/enhanced in proestrus females. Furthermore, sex hormones have been shown to be responsible for this gender-specific immune response following adverse circulatory conditions. More specifically, studies indicate that androgens produce immunodepression following trauma-hemorrhage in males. In contrast, female sex steroids appear to exhibit immunoprotective properties following trauma and severe blood loss. With regard to the underlying mechanisms, receptors for sex hormones have been identified on various immune cells suggesting direct effects of these hormones on the immune cells. Alternatively, indirect effects of sex hormones, ie, modulation of cardiovascular responses or androgen- and estrogen-synthesizing enzymes, might contribute to gender-specific immune responses. Recent studies indicate that sex hormones, eg, dehydroepiandrosterone (DHEA), also modulate the function of peripheral blood mononuclear cells in surgical patients. Thus, the immunomodulatory properties of sex hormones/receptor antagonists/sex steroid synthesizing enzymes following trauma-hemorrhage suggests novel therapeutic strategies for the treatment of immunodepression in surgical patients.

KEYWORDS: Gender. Sex steroids. Hemorrhagic shock. Immune depression. Immunmodulation.

\section{INTRODUCTION}

Several clinical and experimental studies suggest that gender affects humoral and cell-mediated immune responses. In this regard, a remarkable female preponderance of autoimmune diseases, ie, systemic lupus erythematosus (SLE) (female to male ratio of 9:1), Hashimoto's thyroiditis, rheumatoid arthritis, and primary biliary cirrhosis, has been observed in both humans and experimental studies. ${ }^{1-4}$ In addition, higher levels of circulating plasma antibody titers have been found in females compared to males. ${ }^{5}$

aepartment of Surgery, Klinikum Grosshadern - Munich, Germany. ${ }^{b}$ ENT Department, Klinikum rechts der Isar - München, Germany. ${ }^{c}$ Center for Surgical Research, Department of Surgery - Birmingham, AL, USA.

Email: irshad.chaudry@ccc.uab.edu

Received for publication on July 14, 2006.

Accepted for publication on August 07, 2006.
While it is plausible that some sex-linked genes may contribute to the genetic predisposition for the disease, other likely culprits for this gender bias are male and female sex hormones. ${ }^{2,6}$ In this respect, the onset and course of autoimmune lupus in the F1 NZB/NZW mouse model varies depending on the sex steroid environment. In contrast to males, female mice of this strain are known to develop lupus erythematosus. Pre-pubertal administration of 5aðdihydrotestosterone, however, prevents the onset of the disease. ${ }^{7,8}$ Similarly, change of sex steroid environment by castrating male mice leads to development of lupus erythematosus in normally unaffected males. ${ }^{8,9}$ Moreover, administration of estradiol to female mice increased the levels of anti-dsDNA antibodies. ${ }^{10}$ Thus, in contrast to male sex steroids, female sex steroids appear to exhibit immunoenhancing effects on B-cell function. Further support for the notion that male and female sex steroids differently affect autoimmune disease processes comes from 
studies that demonstrate lower androgen and increased estrogen metabolite levels in women with SLE compared to age-matched healthy female controls. ${ }^{11-13}$. Moreover, increased estrogenic activity has been reported in patients with lupus erythematosus. ${ }^{13}$.

Sexual dimorphism also seems to play a role in cellmediated immune responses. In this respect, Calzolari demonstrated as early as 1898 an enlargement of the rabbit's thymus when castrated before sexual maturity, thereby indicating a connection between sexual environment and immunology. ${ }^{14}$. In more recent studies, skin allograft rejection time has been reported to be shorter in males compared to females. ${ }^{15}$. Castration of male mice, however, has been found to balance those gender differences by increasing time for skin rejection. ${ }^{15}$.

The above mentioned studies collectively suggest that gender as well as male and female sex steroids exhibit immunomodulatory properties on humoral and cell-mediated immune functions under normal conditions and following disease processes. In this review article, gender-specific immune responses as well as the effects of sex steroids on cellmediated immunity following shock will be discussed. This article will focus on macrophages and T-cells, since those immune cells are known to be a first line of defense in host resistance and play a central role in the regulation of the immune system. ${ }^{16}$ The aim of this review is to emphasize the importance of gender and the state of the estrus cycle in females on the immune response following trauma and severe blood loss. Furthermore, the potential for modulating sex hormone effects as novel strategies for the treatment of immunodepression will be discussed.

\section{Gender dimorphism in trauma, shock and sepsis}

Several investigators are attempting to elucidate the influence of gender on the individual response to trauma, shock, and sepsis. In this respect, male gender and age are reported to be risk factors for development of sepsis and multiple organ failure following trauma. ${ }^{17-23}$ These epidemiological studies report that the majority of injured victims are young males. ${ }^{20,21}$ Gender differences, however, exist not only in the prevalence of trauma, but also in the increased susceptibility to septic complications after trauma and blood loss as well as after major surgery. In this respect, Offener et al identified male gender as an independent risk factor for the development of severe infection in surgical patients. ${ }^{24}$ In a retrospective study incorporating 4 major sepsis studies, Bone reported a preponderance of morbidity and mortality from sepsis in males as compared to females. ${ }^{17}$ McGowan et al also reported a significantly higher incidence of bacteremic infections in traumatized males than in females. ${ }^{19}$ Furthermore, a retrospective study incorporating 30,286 trauma victims with an injury severity score (ISS) $>15$ demonstrated a significantly higher incidence of pneumonia in males. ${ }^{25}$ Trauma patients with an ISS $<15$ displayed no differences in the incidence of pneumonia. ${ }^{25}$ Moreover, Schroder et al have shown a significantly higher survival rate in women $(74 \%)$ compared to men (31\%) following the onset of sepsis. ${ }^{26}$

In addition to differences in the incidence of genderdimorphic septic complications, gender-specific cytokine patterns have been observed in surgical patients. Oberholzner et al found significantly elevated IL-6 and procalcitonin levels in male trauma patients compared to females. ${ }^{27}$ Wichmann et $\mathrm{al}^{28}$ indicated that despite comparable preoperative cell counts, significant postoperative gender differences regarding B-lymphocyte, T-lymphocyte, Thelper cell counts, and NK cell counts were evident. While only a short, insignificant depression of these immune competent cells was detected in women, men suffered long-lasting (5 days) depression of these cells. Furthermore, women showed a more pronounced immediate (day 1) proinflammatory response (circulating IL-6) after abdominal surgery. ${ }^{28}$ Conversely, Majetschak et $\mathrm{al}^{29}$ did not find gender-specific cytokine responses in trauma patients with an ISS $>16$. In male trauma victims with septic complications, however, increased IL-6 and TNF-a levels were evident. This increase was not observed in female trauma victims with septic complications. ${ }^{29}$

Similar gender-dimorphic findings have been demonstrated in experimental studies following severe blood loss and the induction of sepsis or sepsis-like states (Fig. 1). ${ }^{30-}$ ${ }^{32}$ Female Wistar rats have been reported to be more resistant to lethal circulatory stress induced by trauma or intestinal ischemia. ${ }^{32}$ In addition, female mice in the proestrus state of their estrus cycle tolerate sepsis better than male mice as demonstrated by increased survival rates of females following polymicrobial septic challenge (female survival rate $60 \%$ compared to $25 \%$ in male animals). ${ }^{31}$ This improved survival was associated with maintained splenocyte

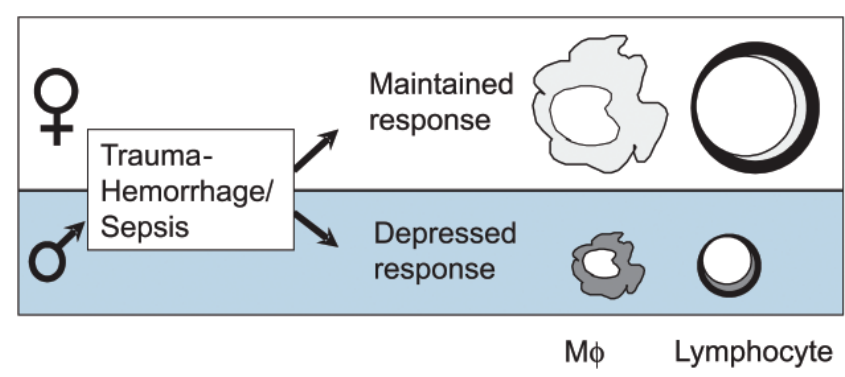

Figure 1 - Schematic illustration of the effect of gender on cell-mediated immune responses following trauma and severe blood loss. 
functions in females compared to depressed immune responses in male mice under those conditions. ${ }^{31}$ Moreover, female mice in the proestrus state of the estrus cycle have been found to exhibit normal/enhanced splenic and peritoneal macrophage cytokine release as opposed to depressed immune responses in males following traumahemorrhage. ${ }^{30}$ Furthermore, proestrus female mice show enhanced release of splenocyte Th1 lymphokines, ie, IL2, IFN-g, compared to depressed Th1 lymphokine release capacities in male mice following trauma-hemorrhage. ${ }^{30}$ Four hours following LPS injection, 4-fold greater plasma IL-1 levels have been found in female mice than in male animals. ${ }^{33}$ Thus, higher levels of proinflammatory cytokines early following the induction of sepsis in female mice might contribute to the better maintained immune responses in females under those conditions. In contrast to Th1 lymphokines, the release of the anti-inflammatory Th2 lymphokine IL-10 has been found to be increased in males and decreased in females following trauma-hemorrhage. ${ }^{34}$ In addition, studies by Altura et al indicate that female rats maintain reticuloendothelial system phagocytic activity following circulatory stress which might further protect immune response under those conditions. ${ }^{32}$

In addition to peripheral immune cells, gender-specific immune responses have also been demonstrated in the thymus, the primary site of T-cell lymphopoiesis. ${ }^{35,36}$ Thymocytes and lymphocytes from normal female mice have been reported to respond more vigorously to exogenous and allergenic antigens than do cells from male mice. ${ }^{36}$ Moreover, an increased thymocyte apoptosis rate was evident in males but not in proestrus females following trauma-hemorrhage. ${ }^{35}$ The increased apoptotic frequency in male animals was associated with a depressed IL-3 release capacity of thymocytes and a significant reduction in thymocyte count. ${ }^{35}$ Since thymocyte apoptosis was determined at 3 days following trauma-hemorrhage, it remains unknown whether an increased rate of thymic apoptosis in females was evident at an earlier or later time point than used in this study. ${ }^{35}$ It also remains to be determined whether the presence of enhanced apoptosis in the T-cell lymphopoetic tissue (eg, the thymus in male mice) contributes directly and/or indirectly to the development of host immunosuppression following trauma-hemorrhage in males through the loss of maturing T-cells. Alternatively, the increased apoptotic rate in males following traumahemorrhage might be an attempt by the immune system to eliminate potential autoreactive $\mathrm{T}$ cells that might be induced in an increased number following traumahemorrhage in males. ${ }^{37}$ Further studies are required to address the question of whether the increased thymocyte apoptotic rate is detrimental to the immune system or whether the increased thymic apoptosis in males prevents additional deleterious effects on the host by eliminating potentially harmful cells. Further support for the importance of the thymus in mediating the effects of sex steroids on the immune system comes from studies using castrated NZB/NZW mice, which develop systemic lupus erythematosus. ${ }^{38}$ In those experiments, thymectomy has been found to abrogate the protective effects of administered androgens on the induction of systemic lupus erythematosus. ${ }^{38}$

Studies have also suggested that the estrus cycle influences the immune responses following hemorrhage. In this regard, studies by Wichmann et al and Krzych et al suggest that the proestrus state of the estrus cycle is characterized by a more vigorous immune response compared to the diestrus state..$^{30,39,40}$ Similarly, the highest levels of IL1 secretion observed in mononuclear cells, have been encountered during the follicular phase of the menstrual cycle in women. ${ }^{41-43}$ These peaks of responsiveness appear to correspond with elevated levels of estrogen and pregnenolone during the proestrus state. ${ }^{40}$ Thus, differences in the estrogenic state might explain why some clinical studies have failed to demonstrate gender differences in the immune response following trauma and adverse circulatory conditions.

\section{Immune response following shock depends on sex steroid environment}

Several studies were conducted in order to elucidate the effect of sex steroids on cell-mediated immune responses following trauma-hemorrhage. In this respect, the responsible hormones in gender-specific immune response originate primarily from the gonads and secondarily from the thymus and the hypothalamus-pituitary gland (Fig. 2). ${ }^{44-50}$ Male gender seems to play an important role in mediating

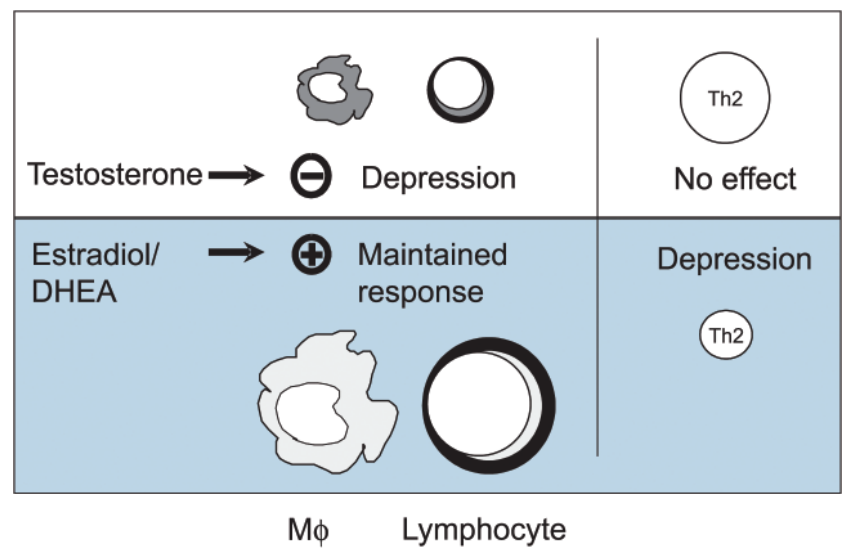

Figure 2 - Schematic illustration of the effect of male and female sex hormones on cell-mediated immune responses, ie, macrophage function and Th1 and Th2 lymphocyte responses following trauma and severe blood loss. 
immunosuppressive effects. Experimental studies indicated that depletion of male sex steroids by castration 2 weeks prior to the onset of trauma-hemorrhage prevented the depression of splenic and peritoneal macrophage cytokine release, as well as splenocyte immune responses following trauma-hemorrhage. ${ }^{47,49-51}$. Moreover, depression of $\mathrm{MHC}$ II expression in splenic and peritoneal macrophages was prevented by depletion of testosterone prior to traumahemorrhage. ${ }^{52}$ In addition, castration of male mice. ${ }^{47,49}$ normalized the increased proinflammatory cytokine release by Kupffer cells normally observed in intact males following trauma-hemorrhage. ${ }^{53}$

To identify whether testosterone itself is responsible for the depression of cell-mediated immune responses following hemorrhage in males, studies were conducted in which female mice were pretreated with 5a-dihydrotestosterone (DHT) for 2 weeks prior to trauma-hemorrhage. ${ }^{45,46}$ The results demonstrated that female mice that had artificially elevated plasma testosterone levels (ie, comparable to males), displayed similar immune responses to hemorrhage as males, namely depression of splenic and peritoneal macrophage function. ${ }^{45}$ Furthermore, pretreatment of female mice with DHT depressed the release of Th1 lymphokines, ie, IL-2, IFN-g, by splenocytes following traumahemorrhage to levels comparable to normal male animals. ${ }^{46}$. A similar change of sex steroid environment by depletion of female steroids by ovariectomy prior to traumahemorrhage depressed cell-mediated immune responses following trauma-hemorrhage, thereby increasing the lethality from subsequent sepsis ${ }^{54}$. In this respect, female sex steroids seem to exhibit enhancing effects on cell-mediated immune responses ${ }^{54-56}$. Recent investigations indicate that castrated male animals treated with DHT exhibit depressed cell-mediated immune responses comparable to normal male animals, whereas additional administration of estradiol prevented the depression of immune responses. ${ }^{47,50}$ Moreover, elevated circulating 172-estradiol levels in proestrus females have been shown to play a direct role in the maintenance of immunocompetence after traumahemorrhage. ${ }^{54}$ In addition, a single dose of estradiol following trauma-hemorrhage and resuscitation restored diminished splenocyte and splenic macrophage immune functions. ${ }^{57,58}$. This improvement in the immune responses was associated with a significantly increased survival rate following the induction of subsequent sepsis. ${ }^{58}$ These findings therefore indicate that the depressed splenic and peritoneal immune responses after trauma-hemorrhage can be normalized by estradiol administration. Similarly, Asai et al demonstrated stimulatory effects of estradiol on the responsiveness of human PBMCs to LPS in vitro. ${ }^{59}$

Thus, estrogen appears to be the causative factor in the maintenance of immunocompetence in females after trauma-hemorrhage, and its administration in ovariectomized or postmenopausal females following traumahemorrhage should be helpful in preventing immune depression under such conditions. The judicious use of female sex steroids or the antagonists of androgens represent potentially novel approaches for the treatment of immune depression following trauma and severe hemorrhagic shock.

\section{Sex steroids differently affect the cardiovascular system}

Recent studies indicate that gender also affects cardiovascular responses. ${ }^{60}$. Castration of male rats 2 weeks prior to the onset of trauma-hemorrhage prevented the depression of myocardial function as evidenced by significantly higher values of heart performance in vivo. ${ }^{61}$ Similarly, treatment of male rats with the androgen receptor antagonist, flutamide, has also been found to prevent the depression of cardiovascular responses following trauma and severe blood loss. ${ }^{62}$ Moreover, trauma-hemorrhage lead to diminished cardiac performance and lower organ blood flow in male animals. ${ }^{63,64}$ Recently, differences in the regulation of plasma and tissue volumes between males and proestrus females during and after trauma-hemorrhage have been found. ${ }^{65}$ In this respect, proestrus females showed an increased circulating blood volume during and after traumahemorrhage which might contribute to the improved immune and organ functions in females. ${ }^{65}$ Moreover, cardiovascular and hepatocellular functions were maintained in proestrus females after resuscitation, whereas they showed depression in males and estrus females. ${ }^{60}$

Estradiol has been found to exhibit protective effects on cardiovascular responses following adverse circulatory conditions. ${ }^{32,66}$ Administration of 17bð-estradiol significantly improved cardiac performance, cardiac output, and hepatocellular function, and attenuated the increase in plasma IL-6 levels. ${ }^{66}$ These studies therefore indicate that female and male sex steroids exhibit divergent effects on cardiovascular responses under normal conditions and following shock. However, the exact relationship between cardiovascular and immune responses contributing to the gender dimorphism following trauma and severe blood loss remains to be elucidated.

\section{Influence of age on gender-specific immune responses}

The influence of gender was investigated not only in young (6-8 weeks old) but also in middle-aged (1 year old) and aged ( 2 years old) mice. Interestingly, in the population of aged mice with decreased levels of sex steroids, a 
reversed gender-related immune response following traumahemorrhage has been identified. ${ }^{34,67,68}$ As opposed to young mice, aged male mice exhibit enhanced release capacities for proinflammatory cytokines by splenic macrophages and Th1 cytokines by splenic lymphocytes compared to depressed release in aged females following traumahemorrhage. ${ }^{34,67,68}$ Changes in the levels of male and female sex steroids with age appear to contribute to the loss of the immunoprotective properties present in younger females. Further studies are required to elucidate whether the advantage in the morbidity and mortality from sepsis might be lost in older females or become comparable to that of aged male mice.

The results described above are in accordance with clinical findings demonstrating a higher mortality rate in septic post-menopausal women compared to male patients ${ }^{69}$ McLauchlan et $\mathrm{al}^{69}$ reviewed a group of 125 patients with a mean age of 66 years who were admitted to the intensive care unit with abdominal sepsis. The hospital mortality rate was $63 \%$ and the factors associated with mortality included age and female sex. In addition, Watanakunakorn's ${ }^{70}$ review of the medical records of patients who fulfilled the criteria for the diagnosis of Staphylococcus aureus endocarditis indicated that, at age 60 or older, female gender was associated with higher mortality. The above studies collectively suggest that age, gender, as well as the state of the estrus cycle in females should be taken into consideration in designing not only experimental, but also clinical studies examining immune responses following trauma-hemorrhage.

\section{Potential mechanisms}

Several studies indicate that sex steroids might exhibit direct immunomodulatory effects on immune cells. In this respect, the presence of estrogen receptors on various immune cells, ie, thymocytes, macrophages, and leukocytes, has been demonstrated. ${ }^{2,71}$. Moreover, the testosterone receptor antagonist, flutamide, restored macrophage and splenocyte as well as cardiovascular function following trauma-hemorrhage in vivo. ${ }^{72,73}$ Thus, sex steroids may modulate immune responses directly via specific receptor mediated processes. Further in vitro studies have demonstrated immunomodulatory properties of sex steroids on immune cells in vitro. In this regard, addition of DHT to the culture medium decreased the release of IL-3 and increased the apoptotic frequency of thymocytes harvested from sham and hemorrhaged animals. ${ }^{35}$ Studies by Chao et al have shown that peritoneal macrophage TNF production can be increased if they are cultured in the presence of estradiol. ${ }^{74}$ Furthermore, the cytotoxic T lymphocyte ac- tivity has been found to be increased after addition of estrogen to the culture media in vitro. ${ }^{2}$

Trauma itself seems to play a role in different immunomodulatory properties of sex steroids. In this respect, under physiological plasma testosterone levels, trauma-hemorrhage is associated with depressed cell-mediated immune responses, whereas sham-operated animals do not show such a depression. ${ }^{45-47,50}$ Furthermore, recent studies indicate that the synthesis of sex steroids is altered following traumahemorrhage. ${ }^{75,76}$ An increased dihydrotestosterone synthesis and a decreased catabolism of this steroid hormone have been demonstrated in male $\mathrm{T}$ lymphocytes following traumahemorrhage whereas the reverse occurs in proestrus females, ie, increased synthesis and decreased catabolism of estradiol take place in the $\mathrm{T}$ lymphocytes. ${ }^{75,76}$

These studies demonstrate several potential mechanisms by which sex steroids might modulate immune responses following adverse circulatory conditions. Nonetheless, we are in the early stages of elucidating the complex interactions of sex hormones and the immune system. Further studies will be required to determine the exact underlying pathways that are influenced by sex steroids under normal as well as following trauma-hemorrhage.

\section{Potential therapeutic strategies}

\section{Androgen receptor antagonists}

Several animal studies have shown beneficial effects of castration by depleting plasma testosterone levels prior to trauma and hemorrhage. In order to transfer those effects into clinical usage, studies mimicking castration by the use of the androgen receptor antagonist, flutamide, were conducted. Administration of flutamide at a dosage of $25 \mathrm{mg} / \mathrm{kg}$ body weight following trauma-hemorrhage and resuscitation normalized the depressed splenic and peritoneal macrophage cytokine release. ${ }^{73}$ In addition, flutamide administration on 3 consecutive days following trauma-hemorrhage not only restored the depressed splenocyte and splenic macrophage cytokine release even after the induction of subsequent sepsis but also significantly decreased the mortality of posthemorrhaged animals subjected to a subsequent septic challenge. ${ }^{72}$ Since flutamide is used in patients with testicular cancer for periods longer than 3 days without major adverse effects, the short-term use of this androgen receptor antagonist in male trauma patients would appear to be a safe and useful adjunct for the treatment of immune and cardiovascular depression under those conditions.

\section{The steroid hormone dehydroepiandrosterone (DHEA)}

Dehydroepiandrosterone (DHEA) is the major circulating steroid hormone in humans. As an intermediate in the 
sex steroid synthesis it can be metabolized to both testosterone and estrogen. In view of the immunoenhancing effects of estrogen administration following traumahemorrhage, DHEA has been reported to exhibit predominantly estrogenic effects in a male hormonal environment. ${ }^{77}$ In additional studies, DHEA administered at a dose of 100 mg per animal prevented the depression of cell-mediated immune responses following trauma-hemorrhage and resuscitation as evidenced by maintained splenic and peritoneal macrophage cytokine release and normalized splenocyte lymphokine release. ${ }^{78,79}$ In addition, administration of DHEA following trauma-hemorrhage significantly improved the survival rate of animals subjected to subsequent sepsis compared to vehicle-treated animals. ${ }^{78}$ Similar to the experimental results, DHEA normalized the depressed proinflammatory cytokine release capacities of human peripheral blood mononuclear cells (PBMCs) following major abdominal surgery in vitro. ${ }^{80}$ The effect of DHEA on PBMC function followed a dose-dependent manner. Thus, DHEA might also exhibit beneficial effects in male trauma patients by preventing the depression of cell-mediated immune responses under those conditions. In the United States, DHEA is widely used as an over-the-counter drug without any serious side effects. In female trauma victims, administration of estrogen appears to be a useful adjunct for decreasing mortality under those conditions.

\section{SUMMARY}

Despite the fact that gender differences in the morbidity and mortality from trauma, shock, and sepsis have been observed in several clinical studies, alterations in the immune functions following shock have been investigated primarily using young male laboratory animals. Recently numerous studies have been initiated investigating the effect of gender, age, and sex hormones on immune responses following shock and trauma. The findings of our studies suggest that low testosterone and/or high estradiol appears to be protective for the host following trauma and severe blood loss. Although the exact underlying mechanism(s) for the immunomodulatory properties of sex hormones on cellmediated immune and cardiovascular responses following trauma-hemorrhage remain unknown, there is evidence that both direct and indirect effects of sex steroids act synergistically in modulating the immune and cardiovascular responses. In this respect, sex hormone receptors have been identified on various immune cells suggesting receptor mediated processes. Other studies suggest the release of secondary mediators that alter immune responses following adverse circulatory conditions. In view of these findings, clinically relevant therapeutic strategies have been developed using the androgen receptor antagonist, flutamide, and/or estrogen or agents with estrogenic effects, eg, DHEA, which might yield safe and useful therapeutic adjunct approaches for the treatment of immune and cardiovascular depression in trauma victims. Moreover, gender should be taken into account when studying the immune or cardiovascular responses following trauma and shock. This notion is supported by the observation that immunmodulatory strategies using IL-10 improved survival in males but not in females following trauma-hemorrhage and subsequent sepsis. ${ }^{81}$

\section{RESUMO}

Angele MK, Frantz MC, Chaudry IH. Hormônios sexuais influenciam a resposta ao trauma e à sepsis - possíveis soluções terapêuticas. CLINICS. 2006;61(5):479-88.

Uma série de estudos clínicos e experimentais demonstram a existência de dimorfismo sexual das respostas imunológicas e orgânicas, bem como da suscetibilidade e morbidade em relação ao choque, ao trauma e à sepse. Respostas imunes celularmente mediadas apresentam-se deprimidas em machos em resposta ao binômio trauma-hemorragia, mas conservados/enaltecidos em fêmeas em proestro. Adicionalmente demonstra-se que os hormônios sexuais são responsáveis por esta dicomotomia de resposta sexualmente específica, em condições cardiovasculares adversas. Estudos específicos indicam que os andrógenos produzem imunodepressão pós-trauma hemorragia em machos. Em contraste, esteróides sexuais femininos parecem exibir propriedades imunoprotetoras após episódios de trauma com ou sem perda importante de sangue. No terreno dos mecanismos subjacentes, foram identificados receptores para hormônios sexuais em várias células do sistema imunológico, sugerindo a existência de efeitos diretos destes hormônios sobre tais células. Alternativamente, observam efeitos indiretos de hormônios sexuais tais como modulação das respostas cardiovasculares das enzimas sintetizadores de andrógeno e estrógeno, que podem contribuir para as estas respostas sexualmente diferenciadas. Estudos recentes indicam que os hormônios sexuais, como por exemplo a dehidroepiandrosterona também modulam a função de células mononucleares da série branca em pacien- 
tes cirúrgicos. Assim, as propriedades imunomodulatórias de hormônios sexuais/antagonistas de receptores/enzimas sintetizadores de esteróides após a ocorrência de trauma ou de hemorragia sugerem o caminho para novas estratégias terapêuticas para o tratamento de imunodepressão em pacientes cirúrgicos.

UNITERMOS: Dimorfismo sexual. Esteroides sexuais. Choque hemorrágico. Depressão immune. Imunomodulação.
1. Roubinian JR, Talal N, Greenspan JS, Goodman JR, Siiteri PK. Effect of castration and sex hormone treatment on survival, anti-nucleic acid antibodies, and glomerulonephritis in NZB/NZW F1 mice. J Exp Med.1978;147:1568-1583.

2. Olsen NJ, Kovacs WJ. Gonadal Steroids and Immunity. Endocr Rev.1996;17:369-384.

3. Hochberg MC, Spector TD. Epidemiology of rheumatoid arthritis: update. Epidemiol Rev. 1990;12:247-252.

4. Sherlock S, Scheuer PJ. The presentation and diagnosis of 100 patients with primary biliary cirrhosis. N Engl J Med. 1973; 289:674-678.

5. Franks CR. Letter: Hormone exposure and lymphocytic impairment. JAMA. $1975 ; 232: 19-20$

6. Grimaldi CM, Hill L, Xu X, Peeva E, Diamond B. Hormonal modulation of B cell development and repertoire selection. Mol Immunol. 2005;42(7):811-820.

7. Roubinian JR, Talal N, Siiteri PK, Sadakin JA. Sex hormone modulation for autoimmunity in NZB/NZW mice. Arth Rheum. 1979;22:1162-1169.
8. Roubinian JR, Talal N, Greenspan JS, Goodman JR, Siiteri PK. Delayed androgen treatment prolongs survival in murine lupus. J Clin Invest. 1979;63:902-911.

9. Kalland T, Strand O, Forsberg JG. Long-term effects of neonatal estrogen treatment on mitogen responsiveness of mouse spleen lymphocytes. J Clin Invest. 1979;63:413-421.

10. Verthelyi D, Ahmed SA. 17 beta-estradiol, but not 5 alphadihydrotestosterone, augments antibodies to double-stranded deoxyribonucleic acid in nonautoimmune C57BL/6J mice. Endocrinology. 1994;135:2615-2622.

11. Lahita RG, Bradlow HL, Ginzler E, Pang S, New M. Low plasma androgens in women with systemic lupus erythematosus. Arthritis Rheum. 1987;30:241-248.

12. Jungers P, Nahoul K, Pelissier C, Dougados M, Tron F, Bach JF. Low plasma androgens in women with active or quiescent systemic lupus erythematsus. Arthritis Rheum. 1982;25:454-457.

13. Lahita RG, Bradlow HL, Fishman J, Kunkel HG. Abnormal estrogen and androgen metabolism in the human with systemic lupus erythematosus. Am J Kidney Dis. 1982;2:206-211. 
14. Calzolari A. Recherches experimentales sur un rapport probable entre la fonction du thymus et celle des testicules. Arch Ital Biol. 1898;30:7177.

15. Graff RJ, Lappe MA, Snell GD. The influence of the gonads and adrenal glands on the immune response to skin grafts. Transplantation. 1969;7:105-111.

16. Chaudry IH, Ayala A. Immunomodulation following hemorrhage and resuscitation. In: Chaudry IH, Ayala A, editors. Immunological Aspects of Hemorrhage. Austin, TX: R.G. Landes Co. 1992:104-127.

17. Bone RC. Toward an epidemiology and natural history of SIRS (systemic inflammatory response syndrome). JAMA. 1992;268:3452-3455.

18. Center for Disease Control. Mortality Patterns - United States, 1989. MMWR. 1992;41:121-125.

19. McGowan JE, Barnes MW, Finland N. Bacteremia at Boston City Hospital: occurrence and mortality during 12 selected years (1935-1972) with special reference to hospital-acquired cases. J Infect Dis. $1975 ; 132: 316-335$.

20. Kong LB, Lekawa M, Navarro RA, McGrath J, Cohen M, Margulies DR et al. Pedestrian-motor vehicle trauma: an analysis of injury profiles by age. J Am Coll Surg. 1996;182(1):17-23

21. Feero S, Hedges JR, Simmons E, Irwin L. Intracity regional demographics of major trauma. Ann Emerg Med. 1995;25(6):788-793.

22. Kher A, Wang M, Tsai BM, Pitcher JM, Greenbaum ES, Nagy RD et al. Sex differences in the myocardial inflammatory response to acute injury. Shock. 2005;23(1):1-10.

23. George RL, McGwin G, Jr., Windham ST, Melton SM, Metzger J, Chaudry IH et al. Age-related gender differential in outcome after blunt or penetrating trauma. Shock. 2003;19(1):28-32.

24. Offner PJ, Moore EE, Biffl WL. Male gender is a risk factor for major infections after surgery. Arch Surg. 1999;134:935-940.

25. Gannon CJ, Pasquale M, Tracy JK, McCarter RJ, Napolitano LM. Male gender is associated with increased risk for postinjury pneumonia. Shock. 2004;21(5):410-414.

26. Schroder J, Kahlke V, Staubach KH, Zabel P, Stuber F. Gender differences in human sepsis. Arch Surg. 1998;133:1200-1205.

27. Oberholzer A, Keel M, Zellweger R, Steckholzer U, Trentz O, Ertel W. Incidence of septic complications and multiple organ failure in severely injured patients is sex specific. J Trauma. 2000;48:932-937.

28. Wichmann MW, Muller C, Meyer G, Adam M, Angele MK, Eisenmenger $\mathrm{SJ}$ et al. Different immune responses to abdominal surgery in men and women. Langenbecks Arch Surg. 2003;387(11-12):397-401.

29. Majetschak M, Christensen B, Obertacke U, Waydhas C, Schindler AE, Nast-Kolb D, Schade FU. Sex differences in posttraumatic cytokine release of endotoxin-stimulated whole blood: relationship to the development of severe sepsis. J Trauma. 2000;48(5):832-840.

30. Angele MK, Schwacha MG, Ayala A, Chaudry IH. Effect of Gender and Sex Hormones on Immune Responses Following Shock. Shock. 2000;4:81-90.

31. Zellweger R, Wichmann MW, Ayala A, Stein S, DeMaso CM, Chaudry IH. Females in proestrus state maintain splenic immune functions and tolerate sepsis better than males. Crit Care Med. 1997;25(1):106-110.
32. Altura BM. Sex and estrogens in protection against circulatory stress reactions. Am J Physiol. 1976;231:842-847.

33. Li P, Allen H, Banerjee S, Franklin S, Herzog L, Johnston C et al. Mice deficient in IL-1b-converting enzyme are defective in production of mature IL-1b and resistant to endotoxic shock. Cell. 1995;80:401-411.

34. Kahlke V, Angele MK, Ayala A, Schwacha MG, Cioffi WG, Bland KI et al. Immune dysfunction following trauma-hemorrhage: Influence of gender and age. Cytokine. 2000;12:69-77.

35. Angele MK, Xu YX, Ayala A, Catania RA, Cioffi WG, Bland K et al. Gender dimorphism in trauma-hemorrhage-induced thymocyte apoptosis. Shock. 1999;12(316):322.

36. Weinstein Y, Ran S, Segal S. Sex-associated differences in the regulation of immune responses controlled by the MHC of the mouse. J Immunol. 1984;132:656-661.

37. Janeway Jr CA. How the immune system discriminates infections nonself from noninfectious self. In: Faist E, Meakins J, Schildberg FW, editors. Host Defense Dysfunction in Trauma, Shock and Sepsis. BerlinHeidelberg: Springer-Verlag, 1993:39-47.

38. Sheridan PJ. Can a single androgen receptor fill the bill? Mol Cell Endocrinol. 1991;76:C39-C45.

39. Krzych U, Strausser HR, Bressler JP, Goldstein AL. Effects of sex hormones on some $\mathrm{T}$ and $\mathrm{B}$ cell functions, evidenced by differential immune expression between male and female mice and cyclic pattern of immune responsiveness during the estrous cycle in female mice. Am J Reprod Immunol. 1981;1:73-77.

40. Krzych U, Strausser HR, Bressler JP, Goldstein AL. Quantitative differences in immune responses during various stages of the estrous cycle in female BALB/c mice. J Immunol. 1978;121:1603-1605.

41. Baron RL. Pathophysiology of septic shock and implications for therapy. Clin Pharm.1998;12:829-845.

42. Hu SK, Mitcho YL, Rath NC. Effect of estradiol on interleukin-1 synthesis by macrophages. Int J Immunopharmacol. 1988;10:247-252.

43. Cannon JG, Dinarello CA. Increased plasma interleukin-1 activity in women after ovulation. Science. 1985;227:1247-1249.

44. Grossman CJ. Possible underlying mechanisms of sexual dimorphism in the immune response, fact and hypothesis. J Steroid Biochem. $1989 ; 34: 241-251$

45. Angele MK, Ayala A, Monfils BA, Cioffi WG, Bland KI, Chaudry IH Testosterone and/or low estradiol: Normally required but harmful immunologically for males after trauma-hemorrhage. J Trauma. 1998;44:78-85.

46. Angele MK, Ayala A, Cioffi WG, Bland KI, Chaudry IH. Testosterone: The culprit for producing splenocyte depression following traumahemorrhage. Am J Physiol. 1998;274:C1530-C1536.

47. Angele MK, Knoferl MW, Schwacha MG, Ayala A, Cioffi WG, Bland $\mathrm{KI}$ et al. Sex steroids regulate pro- and antiinflammatory cytokine release by macrophages after trauma-hemorrhage. Am J Physiol. 1999;277:C35-C42.

48. Zellweger R, Zhu X-H, Wichmann MW, Ayala A, DeMaso CM, Chaudry IH. Prolactin administration following hemorrhagic shock improves macrophage cytokine release capacity and decreases mortality from subsequent sepsis. J Immunol. 1996;157:5748-5754. 
49. Wichmann MW, Ayala A, Chaudry IH. Male sex steroids are responsible for depressing macrophage immune function after trauma-hemorrhage. Am J Physiol. 1997;273:C1335-C1340.

50. Angele MK, Knoferl MW, Ayala A, Bland KI, Chaudry IH. Testosterone and estrogen differently effect Th 1 and $\mathrm{Th} 2$ cytokine release following trauma-haemorrhage. Cytokine. 2001;16:22-30

51. Wichmann MW, Zellweger R, DeMaso CM, Ayala A, Chaudry IH. Mechanism of immunosuppression in males following traumahemorrhage: Critical role of testosterone. Arch Surg. 1996;131:11861192.

52. Mayr S, Walz CR, Angele P, Hernandez-Richter T, Chaudry IH, F. Loehe F, Jauch KW, Angele MK. Castration prevents suppression of MHC class II (Ia) expression on macrophages following trauma-hemorrhage. J Appl Physiol (in press).

53. Ayala A, Perrin MM, Ertel W, Chaudry IH. Differential effects of haemorrhage on Kupffer cells: decreased antigen presentation despite increased inflammatory cytokine (IL- 1, IL-6 and TNF) release. Cytokine. 1992;4:66-75.

54. Knoferl MW, Angele MK, Schwacha MG, Bland KI, Chaudry IH. Preservation of splenic immune functions by female sex hormones after trauma-hemorrhage. Crit Care Med. 2002;30(4):888-893.

55. Friedman D, Netti F, Schreiber AD. Effect of estradiol and steroid analogues on the clearance of immunoglobulin G-coated erythrocytes. J Clin Invest. 1985;75:162-167.

56. Yamamoto Y, Saito H, Setogawa T, Tomioka H. Sex differences in host resistance to mycobacterium marinum infection in mice. Infect Immun. 1991;59:4089-4096.

57. Knoferl MW, Jarrar D, Angele MK, Ayala A, Schwacha MG, Bland K et al. 17 beta-Estradiol normalizes immune responses in ovariectomized females after trauma-hemorrhage. Am J Physiol Cell Physiol. 2001;281:C1131-C1138.

58. Knoferl MW, Diodato MD, Angele MK, Ayala A, Cioffi WG, Bland KI et al. Do female sex steroids adversely or beneficially affect the depressed immune responses in males after trauma-hemorrhage? Arch Surg. 2000;135:425-433.

59. Asai K, Hiki N, Mimura Y, Ogawa T, Unou K, Kaminishi M. Gender differences in cytokine secretion by human peripheral blood mononuclear cells: Role of estrogen in modulating LPS-induced cytokine secretion in an ex vivo septic model. Shock. 2001;16:340343.

60. Jarrar D, Wang P, Cioffi WG, Bland KI, Chaudry IH. The female reproductive cycle is an important variable in the response to traumahemorrhage. Am J Physiol. 2000;279:H1015-H1021.

61. Remmers DE, Bland KI, Cioffi WG, Wang P, Angele MK, Chaudry IH Testosterone: the crucial hormone responsible for depressing myocardial function in males after trauma-hemorrhage. Ann Surg. 1998;227:790799.

62. Remmers DE, Wang P, Cioffi WG, Bland K, Chaudry IH. Testosterone receptor blockade after trauma-hemorrhage improves cardiac and hepatic functions in males. Am J Physiol. 1997;273:H2919-H2925.

63. Wang P, Hauptman JG, Chaudry IH. Hemorrhage produces depression in microvascular blood flow which persists despite fluid resuscitation. Circ Shock. 1990;32:307-318.
64. Wang P, Ba ZF, Burkhardt J, Chaudry IH. Trauma-hemorrhage and resuscitation in the mouse: effects on cardiac output and organ blood flow. Am J Physiol. 1993;264:H1166-H1173.

65. Kuebler JF, Toth B, Rue LW, III, Wang P, Bland KI, Chaudry IH. Differential fluid regulation during and after soft tissue trauma and hemorrhagic shock in males and proestrus females. Shock. 2003;20(2):144-148.

66. Mizushima Y, Wang P, Jarrar D, Cioffi WG, Bland KI, Chaudry IH. Estradiol administration after trauma-hemorrhage improves cardiovascular and hepatocellular functions in male animals. Ann Surg. 2000;232:673-679.

67. Kahlke V, Angele MK, Schwacha MG, Ayala A, Cioffi WG, Bland KI et al. Reversal of sexual dimorphism in splenic T lymphocyte responses after trauma-hemorrhage with aging. Am J Physiol Cell Physiol. 2000;278:C509-C516.

68. Kang SC, Matsutani T, Choudhry MA, Schwacha MG, Rue LW, Bland $\mathrm{KI}$ et al. Are the immune responses different in middle-aged and young mice following bone fracture, tissue trauma and hemorrhage? Cytokine. 2004;26(5):223-230.

69. McLauchlan GJ, Anderson ID, Grant IS, Fearon KC. Outcome of patients with abdominal sepsis treated in an intensive care unit. Br J Surg. 1995;82(4):524-529.

70. Watanakunakorn C. Staphylococcus aureus endocarditis at a community teaching hospital, 1980 to 1991 . An analysis of 106 cases. Arch Intern Med. 1994;20:2330-2335.

71. Cutolo M, Sulli A, Seriolo B, Accardo S, Masi AT. Estrogens, the immune response and autoimmunity. Clin Exp Rheum. 1995;13(2):217-226.

72. Angele MK, Wichmann MW, Ayala A, Cioffi WG, Chaudry IH. Testosterone receptor blockade after hemorrhage in males: Restoration of the depressed immune functions and improved survival following subsequent sepsis. Arch Surg. 1997;132:1207-1214.

73. Wichmann MW, Angele MK, Ayala A, Cioffi WG, Chaudry I. Flutamide: A novel agent for restoring the depressed cell-mediated immunity following soft-tissue trauma and hemorrhagic shock. Shock. 1997;8(4):1-7.

74. Chao TC, VanAlten PJ, Greager JA, Walter RJ. Steroid sex hormones regulate the release of tumor necrosis factor by macrophages. Cell Immunol. 1995;160:43-49.

75. Samy TS, Knoferl MW, Zheng R, Schwacha MG, Bland KI, Chaudry $\mathrm{IH}$. Divergent immune responses in male and female mice after traumahemorrhage: dimorphic alterations in T lymphocyte steroidogenic enzyme activities. Endocrinology. 2001;142:3519-3529.

76. Zheng R, Samy TS, Schneider CP, Rue LW, Bland KI, Chaudry IH. Decreased 5alpha-dihydrotestosterone catabolism suppresses $\mathrm{T}$ lymphocyte functions in males after trauma-hemorrhage. Am J Physiol Cell Physiol. 2002;282:C1332-C1338

77. Ebeling P, Koivisto VA. Physiological Importance of dehydroepiandrosterone. Lancet. 1994;343:1479-1481.

78. Angele MK, Catania RA, Ayala A, Cioffi WG, Bland K, Chaudry IH. Dehydroepiandrosterone (DHEA): An inexpensive steroid hormone which decreases the mortality from sepsis. Arch Surg. 1998;133:12811288. 
Angele MK et al.

79. Catania RA, Angele MK, Ayala A, Cioffi WG, Bland K, Chaudry IH. Dehydroepiandrosterone (DHEA) restores immune function following trauma-hemorrhage by a direct effect on T-lymphocytes. Cytokine. 1998;11:443-450.

80. Frantz MC, Prix NJ, Wichmann MW, van den Engel NK, HernandezRichter T, Faist E et al. Dehydroepiandrosterone (DHEA) restores the depressed PBMC function following major abdominal surgery via the estrogen receptors. Crit Care Med. 2005;33:1779-1786.
81. Kahlke V, Dohm C, Mees T, Brotzmann K, Schreiber S, Schroder J. Early interleukin-10 treatment improves survival and enhances immune function only in males after hemorrhage and subsequent sepsis. Shock. 2002;18(1):24-28. 